\title{
Prezentacja książki Uniwersytety wobec wspótczesnych wyzwań autorstwa kard. Zenona Grocholewskiego
}

Prezentowana książka ${ }^{1}$ dzieli się na pięć grup tematycznych. Nie są one hermetycznie zamknięte, ale są ze sobą powiązane.

\section{Tożsamość uniwersytetu}

Kardynał Zenon Grocholewski ukazuje tę tożsamość w sposób pogłębiony. Kościół przez uniwersytety spełnia powierzony mu przez Jezusa Chrystusa obowiązek i prawo nauczania swojej trzody. Czyni to poprzez dwa rodzaje uniwersytetów: uniwersytety katolickie oraz uniwersytety kościelne. Uniwersytety kościelne zajmują się badaniem nauk teologicznych oraz nauk z nimi powiązanych, ich działalność normuje Kodeks prawa kanonicznego [dalej: KPK] w kanonach 815-821 oraz konstytucja apostolska Sapientia christiana Jana Pawła II z 15 kwietnia 1979 roku. Działalność uniwersytetów katolickich reguluje KPK w kanonach 807-814 oraz konstytucja apostolska Ex corde Ecclesiae Jana Pawła II z 15 sierpnia 1990 roku. Misją uniwersytetu katolickiego jest integrowanie wiedzy wobec jej fragmentaryzacji, dialog wiary i rozumu wobec ich separacji, prymat prawdy obiektywnej i etyki wobec relatywizmu i przerostu technizacji, ukazanie perspektywy teologicznej i służby wobec instrumentalizacji antropologii i zniekształcanie wizji świata. W tej perspektywie uniwersytet katolicki i uniwersytet kościelny to „latarnie” świecące prawdą, to pochodnia ewangelizacji osób, kultury i społeczeństwa. Odwołując się do św. Augustyna, który urząd Piotrowy nazywa „amoris officium”, Kardynał, jak się wydaje, chce tak nazwać uniwersytet

\footnotetext{
${ }^{1}$ Red. ks. prof. dr hab. S. Urbański, Szkoła Wyższa im. Bogdana Jańskiego, Warszawa 2013.
} 
katolicki. Cytuje Benedykta XVI, który powiedział, że uniwersytet narodził się z umiłowania wiedzy i prowadzi do miłości.

Poszukiwanie i głoszenie prawdy wymaga wolności, dlatego uniwersytet potrzebuje wolności i autonomii, która łączy się z odpowiedzialnością. U podstaw wskazań uniwersytetu leży prawda i godność człowieka. Są to wartości podstawowe, których źródłem jest Bóg - Stwórca. Uniwersytety katolickie, które prowadzą badania i prace dydaktyczne $\mathrm{z}$ różnych dziedzin wiedzy, podobnie jak to jest na innych uniwersytetach i wyższych uczelniach, swoją refleksję naukową winny ubogacać światłem Ewangelii, nie pomijając inspiracji filozoficznej. Dlatego Kościół troszczy się, aby na uniwersytetach katolickich była wykładana teologia również dla studentów świeckich. W tym celu należy tworzyć na nich wydziały teologiczne albo instytuty, lub przynajmniej katedry teologii.

Szczególne znaczenie przypisane jest wydziałom teologicznym na uniwersytetach państwowych. Sięgając do początku uniwersytetów, które powstały w łonie Kościoła w średniowieczu, trzeba zaznaczyć, że kluczową rolę odegrały w nich wydziały teologiczne. Dzisiaj wydział teologiczny na uniwersytecie może stać się źródłem dialogu między wiarą i rozumem, a przez to ubogacić uniwersytety, również uniwersytet może wzbogacić wydział teologiczny. Ta wzajemna wymiana dóbr ma służyć kulturze. Zresztą każdy uniwersytet winien służyć kulturze poszczególnych narodów, a także kulturze ogólnoludzkiej. Postępujący proces globalizacji potrzebuje uniwersytetów, w tym uniwersytetów katolickich. Mają one służyć prawdziwemu dobru osoby ludzkiej, jak również społeczeństwu, promując skuteczną solidarność i cywilizację miłości.

Uniwersytet jest bardziej wspólnotą niż instytucją. W tej wspólnocie niezastąpioną rolę spełniają teologowie. Mają oni być nie tylko „naukowcami wiary”, ale zarazem świadkami wiary. Zadaniem Kościoła jest nie tylko ochrona teologów, ich praw, ale także praw podstawowej grupy w łonie wspólnoty akademickiej, jaką stanowią studenci, którzy mają prawo do korzystania z nauczania wiary. Kościół troszczy się nie tylko o nauczanie teologii, o jej wykładowców i studentów, troszczy się także o nauczanie prawa kanonicznego, filozofii chrześcijańskiej, historii Kościoła i innych dyscyplin kościelnych. W nauczaniu prawa kanonicznego, w wykładaniu KPK należy uwzględnić eklezjologię soborową oraz wszystkie normy i koncepcje, które czerpią inspirację z nauczania Vaticanum II. Odnowa studiów filozoficznych uwzględnia otwarcie rozumu na wiarę oraz potrzebę wspierania wiary przez rozum.

\section{Posłannictwo uniwersytetu we współczesnym świecie}

Posłannictwem uniwersytetu jest według kard. Grocholewskiego przygotowanie misjonarzy prawdy. Być misjonarzem prawdy, to uznać, że rozum ludzki może dojść do poznania prawdy obiektywnej, to także dojść do prawdy przekraczającej tylko 
dane empiryczne, do prawdy absolutnej, ostatecznej i fundamentalnej. Jednak być misjonarzem prawdy to coś więcej, to przede wszystkim uznać, że wiara i rozum to dwa skrzydła, na których duch ludzki unosi się do kontemplacji prawdy² ${ }^{2}$ Ta kontemplacja zaś opiera się na miłości prawdy, całej prawdy, która rodzi „gaudium de veritate".

Wobec różnych zagrożeń wiary, która we współczesnym świecie w niektórych krajach wygasa jak niepodsycany płomień, potrzeba źródła energii, by połacie świata nie stały się pustynią. Tym źródłem energii podsycającym wiarę mają być uniwersytety kościelne i katolickie. Stąd uniwersytety mają być szkołami wiary i wspólnotami wiary. Pisze Kardynał:

W związku z tym nauczyciele i studenci uniwersytetów katolickich są zaproszeni do pozostawania zawsze w ścisłym zjednoczeniu z Chrystusem i jego Kościołem, zasilając swoje studia i nauczanie modlitwą, bo bez modlitwy i bez kontemplacji nie możemy nawet prawidłowo zrozumieć prawdy wiary ${ }^{3}$.

Bóg powołuje uniwersytety katolickie do ewangelizowania poprzez edukację i do edukowania poprzez ewangelizację.

Kardynał Grocholewski nie tylko bardzo często przywołuje wypowiedzi błogosławionego Jana Pawła II na temat zadań uniwersytetu, ale także podkreśla jego zasługi dla promocji studiów kościelnych, rozwoju nauki, prawodawstwa dotyczącego organizacji nauki i dla erygowania różnorodnych instytucji naukowych. Jan Paweł II promulgował dwa kodeksy: KPK i Kodeks kanonów Kościołów wschodnich [dalej: KKKW], które normują funkcjonowanie uczelni kościelnych i katolickich. Jest autorem konstytucji apostolskiej Sapientia christiana, regulującej działalność uniwersytetów kościelnych. Jego wkład w jej przygotowanie zaczął się już wtedy, gdy był arcybiskupem krakowskim. Jest także autorem konstytucji apostolskiej Ex corde Ecclesiae regulującej działalność uniwersytetów katolickich.

Jednym z wiodących tematów, który Jan Paweł II wskazywał jako posłannictwo uczelni, jest obrona człowieka, jego godności i jego praw. W tej dziedzinie miał on wielkie doświadczenie, sięgające okupacji niemieckiej, związanej z niesłychaną pogardą i poniewieraniem człowiekiem, dalej, doświadczenie dyktatury komunistycznej depczącej fundamentalne prawa człowieka, jak choćby prawo do wolności, a także doświadczenie drapieżnego kapitalizmu, poniewierającego i wykorzystującego człowieka. W uczelniach Jan Paweł II postrzegał areopagi obrony i głoszenia praw ludzkich i wychowywania do ich poszanowania. Oprócz tego ukazywał uczelnie jako instytucje zajmujące się różnorodną i rozległą problematyką. Pisze Kardynał:

\footnotetext{
${ }^{2}$ Por. Jan Paweł II, Fides et ratio, 1.

${ }^{3}$ Z. Grocholewski, Uniwersytety wobec współczesnych wyzwań, dz. cyt., s. 154.
} 
Jeśli postawimy sobie pytanie o wkład treściowy Jana Pawła II w dziedzinę studiów i nauk, to zarysuje się bardzo rozległa problematyka, traktowana przez niego z pasją jako wielkoduszne dzielenie się swoimi przemyśleniami, bardzo konstruktywnymi, z innymi, jak również jego troska o depozyt wiary i prawdziwy postęp ludzkości ${ }^{4}$.

Jan Paweł II, akcentując godność człowieka i jego prawa, w szczególny sposób podkreślał prawo do wolności nauki i związanej z nią autonomii uniwersytetów.

We współczesnym życiu, również na wielu uczelniach, można zauważyć szerzące się fałszywe i błędne teorie, koncepcje i ideologie. Są wśród nich: zagubienie sensu życia i nihilizm w różnych postaciach, separacja wiary i rozumu, materializm praktyczny, osłabienie wrażliwości na Boga i człowieka, nowa mentalność scjentystyczna, sojusz demokracji z etycznym relatywizmem i kryzys kulturowy. Kardynał stawia pytanie: „Jak znaleźć wyjście z labiryntu, w którym się znaleźliśmy?” Daje odpowiedź: „Właśnie tutaj swoją kluczową rolę powinien odegrać uniwersytet katolicki w służbie osoby ludzkiej i społeczeństwa”5. Pisze dalej: „Sposób rozwiązania jest długoterminowy i wiedzie przez edukację i kulturę. Wiemy, że społeczeństwa nie przekształcają się wskutek niecierpliwych rewolucji, ale drogą cierpliwej edukacji”’6. Misja uniwersytetu katolickiego ma także wspólne zadania we współczesnym świecie, wymaga jednak pewnej specyfikacji w różnych częściach świata, np. na Bliskim Wschodzie czy w regionach zdewastowanych przez system komunistyczny, np. w pewnych częściach w Europie.

\section{Uniwersytet a nowa ewangelizacja}

Mówiąc o nowej ewangelizacji, stwierdza Kardynał, trzeba ustalić pojęcia. Między ewangelizacją postrzeganą jako zwyczajna opieka duszpasterska nad wiernymi, a nową ewangelizacją, czyli głoszeniem Ewangelii na terenach, gdzie niegdyś żyjący tam ludzie byli gorliwymi chrześcijanami, żyli wiarą, która przenikała ich życie osobiste i społeczne, dzisiaj zaś stali się obojętni religijnie i żyją, jakby Bóg nie istniał, nie da się ustalić zamkniętych granic i barier. Tym ludom i narodom trzeba głosić tę samą Ewangelię, ale w sposób bardziej skuteczny, stosując nowe metody, nowy dynamizm i nową gorliwość. W tej dziedzinie ważna rola i wielka odpowiedzialność spoczywa na uniwersytetach katolickich i kościelnych. Uniwersytety te mają być znakiem żywym i obiecującym, tzn. głoszącym Ewangelię z dynamizmem i zaangażowaniem. Do takiego ewangelizowania ma przygotować uniwersytet.

\footnotetext{
${ }^{4}$ Tamże, s. 171.

${ }^{5}$ Tamże, s. 197.

${ }^{6}$ Tamże, s. 202.
} 
Wobec wyzwań nowej ewangelizacji uniwersytet winien realizować trzy swoje cele: poszukiwanie prawdy, poszukiwanie Boga i poszukiwanie człowieka. Spełniając te cele, uniwersytet winien kształtować wychowanków na ludzi wykształconych, przygotowanych do wykonywania poważnych obowiązków społecznych oraz na świadków wiary w świecie. Sam uniwersytet ma dawać świadectwo o charakterze instytucjonalnym Chrystusowi i Jego orędziu, które jest potrzebne zarówno w społeczeństwach naznaczonych sekularyzmem, jak i tam, gdzie jeszcze Chrystus i Jego orędzie nie są znane. Ta misja, którą Kościół z wielką nadzieją powierza uniwersytetom katolickim, ma żywotne znaczenie kulturowe, społeczne i religijne i dotyczy przyszłości rodzaju ludzkiego.

\section{Humanizm chrześcijański}

Kardynał Grocholewski bardzo mocno wiąże posłannictwo uniwersytetu z troską o człowieka, jego rozwój, godność, wychowanie i wykształcenie. Nawiązuje do starej sentencji zarówno greckiej, jak i łacińskiej: ,genus humanum arte et ratione vivit”. Człowiek żyje prawdziwie ludzkim życiem dzięki kulturze. Kultura jest właściwym sposobem istnienia i bytowania człowieka. W historii rozwoju kultury ogólnoludzkiej przełomowe i decydujące znaczenie miało wkroczenie w jej dzieje Objawienia Bożego. Objawienie stało się zaczynem nowej kultury, czyli nowego podejścia do człowieka i sensu życia. Pisze Kardynał:

Tymczasem w chrześcijaństwie Prawda, Dobro i Piękno związane zostają realnie z samym Bogiem, któremu przysługują w stopniu absolutnym, ale które dzięki stwórczości Boskiej stają się udziałem stworzonego świata i człowieka, dla którego z kolei stają się najważniejszym wyznacznikiem życia swoiście ludzkiego, a więc życia na sposób kultury?

Niektóre współczesne ateistyczne trendy chcą odrzucić Boga, lecz to odrzucenie jest równocześnie atakiem na człowieka i odrzuceniem człowieka, który według przywołanych trendów przestaje być ,imago Dei”. Skutkiem tego jest alienacja i nihilizacja człowieka, którego traktuje się jak konsekwencję produktów społecznych i ekonomicznych czy konsekwencję instynktów, lub konsekwencję prostej ekspresji genów. Te poglądy są głęboko antyludzkie i antyhumanitarne. Wyrażają się w takich prądach myślowych, jak strukturalizm, egzystencjalizm czy materializm dialektyczny. Antropologia zbudowana na takich poglądach prowadzi do „kultury śmierci”. Odpowiedzią i rozwiązaniem jest przyznanie właściwego miejsca Bogu i człowiekowi w całokształcie humanizmu.

7 Tamże, s. 286. 
U podstaw humanizmu chrześcijańskiego w jego dziejach i rozwoju była teologia i tak powinno być także dzisiaj. Daleko dziś posunięta specjalizacja i rozdrobnienie nauk wpływa także na teologię. Stąd trzeba szukać zasady zjednoczenia. Jest nią Jezus Chrystus. Pisze Kardynał: „Tajemnica Chrystusa i historia zbawienia jawią się tutaj zatem w ich wyjątkowej zdolności spajania"s. Jezus Chrystus jest pełnią prawdy, która wyzwala człowieka i inspiruje, opromienia i ożywia humanizm chrześcijański.

\section{Kultura nośnikiem wartości chrześcijańskich}

W posłannictwie uniwersytetów katolickich, zgodnie z nauczaniem kardynała Grocholewskiego, ważną rolę odgrywa promocja kultury. Współcześnie zagrożeniem dla nauki jest zmniejszające się zainteresowanie dyscyplinami humanistycznymi i wynikająca $z$ tego tendencja do ograniczenia poznania człowieka i poznania prawdy. Następnym zagrożeniem jest podporządkowanie badań naukowych partykularnym interesom pozanaukowym, jak i manipulowanie czy fałszowanie badań naukowych. To powoduje ograniczenia w poszukiwaniu prawdy. W konsekwencji kultura popada w relatywizm i ulotność. Do tego dochodzi dysharmonia między postępem naukowo-technicznym, a postępem etyczno-moralnym, na niekorzyść tego ostatniego. Droga wyjścia prowadzi poprzez dialog wiary i kultury. Wiara i kultura nie są sobie obce, lecz nierozerwalnie złączone u podstaw, gdyż zjawisko kultury u swoich ontologicznych podstaw posiada wewnętrzny wymiar religijny. Próba rozbicia tej łączności wyrządza szkodę człowiekowi i kulturze. Pisze Kardynał:

W takim dialogu ogromne znaczenie ma refleksja teologiczna w łonie uniwersytetu. Promuje bowiem konstruktywny dialog w prawdzie, przyczyniając się do uniknięcia dualistycznej koncepcji ludzkiej wiedzy a zatem odseparowania Ewangelii od kultury, wiary od rozumu?

Dialog między wiarą i kulturą, troska o wiedzę obejmującą wizję i formację integralną człowieka, obiektywne badania i przekazywanie prawdy służą człowiekowi i prawdziwemu postępowi. Kultura służy także harmonii przeżywanej wiary z badaniami naukowymi, prowadzącej do świadectwa chrześcijańskiego życia. Współczesną kulturę trzeba budować w oparciu o przeszłość. Ciągłość tradycji uniwersyteckich, ich pielęgnowanie służy postępowi i kulturze. W tym procesie nie można pominąć współpracy między kulturami. Uniwersytet winien stać się miejscem spotkania kultur przy zachowaniu własnej tożsamości. Spotkanie kultur dosięga globalizacja. Jest ona prawdziwym wyzwaniem, którym trzeba tak pokierować, aby wyeliminować jej negatywne efekty. Pisze Kardynał:

\footnotetext{
${ }^{8}$ Tamże, s. 316.

${ }^{9}$ Tamże, s. 343.
} 
Promowanie globalizacji, która byłaby w służbie osoby ludzkiej rozpatrywanej całościowo i która byłaby w służbie wszystkich ludzi, w duchu prawdziwej solidarności i autentycznej miłości, jest właśnie współistotna uniwersytetowi, który zakłada sobie wkład do prawdziwego postępu ludzkości. Na tym polu znaczącą rolę mają oczywiście do odegrania wydziały teologiczne, które ze swej natury są powołane do nawiązywania konstruktywnego dialogu z innymi wydziałami i z całym światem uniwersyteckim ${ }^{10}$.

W tej perspektywie wartości chrześcijańskie, takie jak: rodzina, godność ludzka, sprawiedliwość, solidarność, miłość, nadzieja, poszanowanie życia ludzkiego we wszystkich jego aspektach, poszanowanie każdej osoby ludzkiej i jej niezbywalnych praw, staną się źródłem inspiracji i dadzą odpowiedź na wielorakie wyzwania współczesnej globalizacji. Tak postrzegana globalizacja może służyć całokształtowi kultury ogólnoludzkiej.

Reasumując, trzeba powiedzieć, że prezentowana książka stanowi niezwykle cenny zbiór wypowiedzi kardynała Grocholewskiego skierowanych do uniwersytetów i o uniwersytetach. Wartość tego zbioru wzrasta także z tego powodu, że zawiera on bardzo aktualne wskazania, ukazujące realne możliwości odrodzenia i odnowienia współczesnych uniwersytetów. Trzeba zaznaczyć, że te wskazania i pouczenia dotyczą nie tylko uniwersytetów katolickich i kościelnych, ale mogą być pomocne wszystkim uniwersytetom. Wywody Kardynała uwzględniają nie tylko aktualną sytuację szkolnictwa wyższego w świecie, ale sięgają też do przeszłości, historii i tradycji. Dzięki temu tworzą swoiste „nova et vetera”. Przywołana w książce argumentacja obficie czerpie z bogactwa nauczania w Kościele, w szczególności z nauczania błogosławionego Jana Pawła II i Benedykta XVI. Uważam, że trzeba za to dzieło wyrazić wdzięczność kardynałowi Zenonowi Grocholewskiemu, redaktorowi ks. prof. dr. hab. Stanisławowi Urbańskiemu i Szkole Wyższej im. Bogdana Jańskiego.

${ }^{10}$ Tamże, s. 369. 